\title{
Initiating the learning processes at the preschool and lower primary level: Challenges and possibilities
}

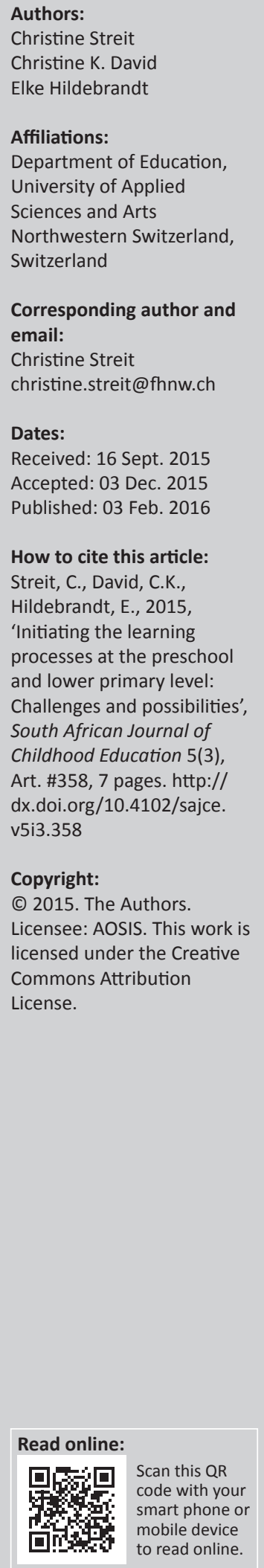

The intended convergence of preschool and school education in accordance with educational policy is challenging. Firstly, one must become aware of the different institutional cultures, and secondly, one needs to be aware of existing similarities and develop common didactic ideas. This article presents a model, based on the situation in German-speaking countries. The model as a basis for discussion - describes specific features of teaching at this level and at the same time provides a framework for the teachers' activities. The aim is to make appropriate didactic decisions in an environment alternating between free and instructed activities for children as well as between specific and interdisciplinary orientation. The model and its potential will be discussed on the basis of a practical example.

\section{Introduction: Institutional framework and teaching practice at the preschool and lower primary level}

The traditionally developed training institutions at preschool and primary levels are currently involved in the processes of change. Following the results of international studies, such as Trends in International Mathematics and Science Study, Programme for International Student Assessment and Progress in International Reading Literacy Study, the focus in German-speaking countries has also been directed increasingly on early education. International studies on education in early childhood, such as National Institute of Child Health and Human Development(NICHD 2002) and The Effective Provision of Pre-School Education (Sylva et al. 2004), were thus received with particular interest. And yet, the structures in the German-speaking countries are by no means uniform. Since 1996, a child in Germany has had the right to a place in kindergarten from the end of his/her third year and since 2013 the right to a place in a crèche from the end of his/her first year. However, attendance is voluntary and the responsibility for the institutions lies with the social ministries of the federal states and not with the ministries of education. On the basis of the agreement reached between the cantons in Switzerland regarding the harmonisation of compulsory schooling, the so-called HarmoS-Konkordat (EDK 2007), the kindergarten in Switzerland is part of the primary school and will soon be subject to compulsory school attendance, thus making attendance compulsory from the child's fourth year (Vogt 2010; Wannack 2010). In Austria, on the other hand, there is neither the right to a kindergarten place nor the obligation to attend it. If there is a vacancy, a child can attend kindergarten from the age of 3. A preschool class such as Grade $\mathrm{R}$ in South Africa does not exist in any of the three countries. In some cases, children who have completed their sixth year of life but are not yet considered to be school-ready, attend an entrance or preschool class in order to be specifically prepared for school.

The kindergarten has the specific focus of facilitating the transfer from preschool to school education (Wannack 2010). Kindergarten and school are linked through a common educational mandate (Honig, Joos \& Schreiber 2004). Both institutions are thus responsible for designing their educational efforts in such a way that the transition is smooth and the continuity of the children's educational development is assured (Wannack et al. 2006). This will succeed if both kindergarten and school are guided by common, all-encompassing educational goals and if they are able to cooperate in this regard.

In principle, the political framework for cooperation across the boundaries of the institutions is most favourable in Switzerland because the kindergarten has increasingly become a part of the primary school, which facilitates cooperation across the boundaries of the two institutions. There are also other areas where initiatives are implemented, for example, in specialist preparatory activities in the kindergarten, as well as in the introduction of open forms of learning in the lower grades of the primary school. Although the scope for creative freedom within the framework of the kindergarten is perceived to be greater than in the school (Wannack 2004:173), it is clear that in both institutions the 'available space is being designed in terms of living, learning and playing areas' (Wannack 2004:174). 
Despite these approaches, in practice differences become apparent in the different organisational structures and concepts (Wannack 2010), which are indicative of different traditions in the two educational institutions. This also becomes apparent when one considers that in Germany free play and general preparation for life are seen by the educators as well as by children and parents as essential elements of the kindergarten, whilst instructed and subject-oriented learning and assessment are regarded as essential elements of the school (Griebel \& Niesel 2002; Niesel, Griebel \& Netta 2008). Because school-related didactics has a long theoretical tradition (Terhart 2008) and is publically considered to be more relevant, there is a perceived danger that the specific features of the kindergarten could lose their meaning and that the central aspect of the interconnection of the two institutions could be reduced to the question of 'to what extent learning in the kindergarten is also geared towards the subsequent learning in school' (Rossbach et al. 2010:36). One could thus also fear a possible transformation of the kindergarten into a 'school-like' institution (Draude 2006).

The challenge thus lies not only in being aware of the different institutional cultures, the prevailing opinions in educational theory ${ }^{1}$ and the (subject-specific) didactic traditions but also in recognising what they already have in common, in order to build on these and to develop compatible didactic ideas, which take the values of the specific individual cultures into consideration. This would make high demands of the teachers in the entrance phase and thus also on their training and further training.

Theoretical discussions of this topic have already come up with various models and concepts that describe, in particular, specialist and interdisciplinary learning in the kindergarten with regard to transfer possibilities to the primary school phase (Kluczniok, Rossbach \& Grosse 2010; Rossbach et al. 2010; Royar \& Streit 2010; Wannack, Arnaldi \& Schütz 2009). However, there is no model that deals on the one hand with the specific aspects of teaching in the entrance phase and on the other hand with the professional profiling of the teachers in this educational phase. Such a model is illustrated in the following discussion.

\section{The integration of teaching dimensions in preformal education}

Teaching always oscillates around the question of the selection of teaching content and goals and the related didactical-methodical structuring of the lessons (Terhart 2008). The contents and the goals can be both subject-specific and interdisciplinary in nature and the implementation of the lesson can be guided in various ways by the teacher. This applies basically to all school grades. Whilst teaching in the higher grades is more oriented towards the subject teacher and the subject systems, learning and teaching and the design of the learning arrangements, particularly

1 Bülow (2011) also refers to the significance of comparable opinions of kindergarten and primary school teachers with regard to educational theory.

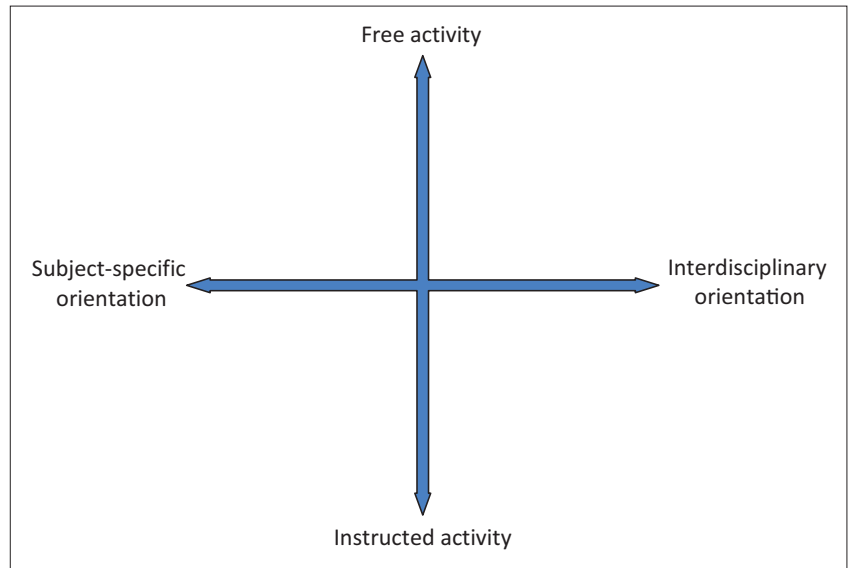

FIGURE 1: Two central dimensions of learning and teaching at the preschool and primary levels.

in the area of preschool education, is less limited by fixed time schedules, a clearly defined selection of subjects and assessments. In the lower grades of the primary school, the class teacher carries the main responsibility for teaching and structures a large percentage of the teaching time. This is also reflected in the teacher's training for the educational grades of the 4- to 8-year olds: as a rule, the teachers are trained as all-rounders in all subjects and teaching areas rather than as subject teachers.

In the following model, these dimensions are discussed. Both aspects move between two poles in various structures and forms (Figure 1): on the one hand, they move between a subject-specific and an interdisciplinary ${ }^{2}$ orientation, and on the other hand between free activities and instructed activities of the learners, which are observed, accompanied, guided, that is controlled in various ways by the teacher.

A special feature of learning and teaching in the early grades is the possibility of seeing the various 'poles' having equal value and regarding them simultaneously. With this, the model does not aim to position the teaching in the kindergarten and the primary phase in a specific quadrant, to replace the instructed activities with free activities (Rossbach 2010) or to develop from subject-oriented teaching to 'interdisciplinary' (or integrated) teaching, but rather to integrate the poles. With the poles being 'of equal value and simultaneous', this would mean that teaching can and must develop within the entire exposed fields and that the teacher must have all four poles in mind simultaneously when guiding the lessons. Roux (2008:22), for example, proposes a similar 'as well as rather than an either/or' approach when she emphasises that it would be counterproductive to play off 'subject-didacticalinstructive procedures against exclusively child-oriented learning in didactic situations'.

2 This article will not deal with the confusing terminology concerning teaching of interdisciplinary subjects, complementary subjects and cross-subject matters (viz in this regard Geigle 2005; Huber 2009; Künzli David \& Bertschy 2010). This article will this regard Geigle 2005; Huber 2009; Kunzli David \& Bertschy 2010). This article will use the term 'interdisciplinary' as an umbrella term for teaching (interdisciplinary teaching) that encompasses numerous subjects (as central structural units in primary school) and teaching areas (as specialist kindergarten units) (in a projectorientated lesson, for example, various subjects will deal with the same topic) Such interdisciplinary orientation does not therefore refer to so-called generic competencies such as, for example, self-, social- or method-competencies, that can be aspired to in subject-specific as well as interdisciplinary teaching. 
We argue that this model is suitable for analysing, planning and designing lessons, proceeding from the intentions of the teacher's activities and keeping in mind the dimensions described above with regard to prioritisation and movements in the model. Movement in the model means the description of sequences of a teacher's activity within the poles on both dimensions within a specific timeframe or in a specific teaching sequence. The two dimensions should not be understood as 'metric scales', that is the real activities of the teacher cannot be positioned at a fixed point. However, prioritisations and movements in the model can be made visible or explained. At the same time, the model has a descriptive as well as a normative function. It can describe - comparatively - the actions of the teacher, but it can also serve as a guide for one's own activities. The latter aims to make use of the entire spectrum that the model offers, thereby considering both the subject and the interdisciplinary goals and stimulating the related learning processes with the children in free and instructed phases.

Hereafter, both dimensions with their respective poles will be described in such a way that the abovementioned relativity, in particular, and the dynamic interconnection of the poles in the teacher's activities for this specific educational phase become apparent both within the framework of lesson planning as well as for the activities in concrete teaching situations. The individual poles should thus be understood especially as analytical categories with regard to the specific and situation-related intention of the teacher.

\section{The 'subject-specific and interdisciplinary orientation' dimension: an educational theory perspective}

Teaching that prepares children for a life in this complex world requires an integration of content and its accessibility to young children. They must learn to become responsible for themselves and for others and learn to reconstruct a complex picture of the world (Duncker 1997a, 1997b). They need to learn to reflect on the world and they need to be assessed on how they learn to do all this. This is not an easy brief for early education. In order to apply this in the teaching situation, it means that the complexity must be both shown and, at the same time, reduced. Subjects and areas of education represent specific structures of reality (Tenorth 1999) and offer categories for the 'readability the world' (Blumenberg 1980). They assist us in observing, interpreting and structuring reality (Huber 2001, 2009). Differentiation and delimitation are prerequisites for all observations and also for all understanding - learning thus also always implies finding new ways of demarcation (Kahlert 1997). An interdisciplinary approach should thus always also refer to the subjects/educational areas and their function of generating and structuring knowledge, and accordingly should focus on the contents, ways of thinking and understanding and designing the subject matter of the relevant subjects/educational areas and then combine or contrast them, as the case may be.
In this way, meaningful learning as well as insight into the significant function of subjects/educational areas is made possible. In teaching that is geared towards the experienced reality of the child (Klafki 1998), subject-specific and interdisciplinary learning are thus mutually dependent: subject-specific learning arrangements are always related (also indirectly) to interdisciplinary learning and interdisciplinary learning always refers to subject-specific learning.

In order to meet the above requirements, it does not suffice, with regard to interdisciplinary learning, to simply present the contents of various subjects one next to the other (see, in this regard Di Giulio, Künzli David \& Defila 2008). The subjects and educational areas should rather be integrated with regard to questions of overriding importance - that can only be dealt with from a multiperspective ${ }^{3}$ point of view - or contrasted in such a manner that their specific manner of observation, expression and understanding becomes clear (Huber 2009): By combining different subject contents and approaches, a multiperspective reconstruction of reality becomes possible. In this way, it also becomes clear that the acquisition of knowledge depends on different professional approaches, interests, etc. and 'invariably results in the realisation that reality can never be understood unambiguously and objectively, independent of our own input' (Popp 1997:143). By contrasting various professional approaches, it becomes possible to clarify the merits and limits (e.g. the aspect reduction or the educational potential with regard to socially relevant, complex problems and questions) of the subjects or educational areas (Klafki 1998). Interdisciplinary teaching 'thus makes it possible to obtain a meta-level of understanding' (Duncker 1997b:126). It is, however, of central importance to consciously integrate this meta-level of the discussion around the observation, interpretation and structuring of the everyday world into the teaching process and to reflect on it together with the children (Valsangiacomo, Widorski \& Künzli David 2014).

\section{The dimension 'Free activity and instructed activity' based on learning theory}

This dimension is directed at the children's activities that are initiated by the teacher or are selected freely by the children, whereby the (none) availability of certain materials already limits the children's freedom. Thus, it is about the degree of control by the teacher. The nature and intensity of the control can vary greatly. The teacher's actions are always related to the goal of initiating certain learning processes in the children. However, the latter cannot be controlled, only guided. According to constructivist understanding, learning is a process whereby the individual actively constructs knowledge or nets of knowledge and his own understanding thereof (Piaget \& Szeminska 1975; Reinmann-Rothmeier \& Mandl 1997; Weinert \& Helmke 1997) or, in contact with others, 'co-constructs' (Fthenakis et al. 2005; Siraj-Blatchford 2007;

3 The term multi-perspective refers in this article to both subject- and participantperspectives. 
Sylva et al. 2004). However, the emphasis of the constructive activity on the part of the learner should not be interpreted in such a way that no instructional efforts are required from the teachers (Giest 2012). This would be the equivalent of an unacceptable transfer of learning psychology-based statements to teaching, which Meyer (2004) refers to as a 'constructivist trap'. Here, an instructional teaching style is associated with an active teacher and a passive learner, whilst a constructivist teaching style is associated with a rather more passive teacher and an active learner. The value of free activity in the kindergarten lies in the fact that here one has to do with a high measure of intrinsic motivation, which per definition goes hand in hand with high self-determination. The need for autonomy and an experience of competency is met in the sphere of free activity (Deci \& Ryan 1985, 1993). Nevertheless, instructions also play an important role in this regard. Mandl, Gruber and Renkl (1995) already postulated almost 20 years ago that instructions at suitable moments are necessary for optimum learning in terms of constructive processes because only they open the way to acquiring useful knowledge, which can lead to successful action, and Möller (2012) declares herself in favour of 'construction through instruction'. The empirical findings in the last few years confirm the significance of instructional activity on the part of the teacher (e.g. findings from early scientific learning: Hardy et al. 2006; Klahr \& Nigam 2004) or make it clear that it is not primarily the observed activity of the learner, but rather the cognitive activation that the teacher's activity initiates in the learner that is decisive for successful cognitive learning processes (Meyer 2009). The meta-analysis by Alfieri et al. (2011) of discovery learning shows that the approaches of guided discovery are superior to pure, unassisted discovery with regard to the efficiency of the acquisition of knowledge.

Against the background of these insights, the dimension 'free and guided activities' describes a larger bandwidth of observed activities of the child that take place within a framework dictated by the teacher. It is the teacher's task to adapt the nature and intensity of the control within the learning arrangement in such a way that it stimulates the children to analyse the content which they have either chosen themselves or been given. This dimension thus looks directly at the activity or indirectly at the intentions of the teacher. Behind this is then the question of the successful guidance and control of the child's learning processes by the teacher. A consciously structured communication process, which in turn offers the opportunity for individual support by the teacher, is seen to be beneficial (Krammer 2010; Rogoff 1990; Wannack, Schütz \& Arnaldi 2009). Particularly, the verbal interaction amongst children, as well as between children and teacher, appears to play an important role because it is through this that communal knowledge is constructed (Mandl, Gruber \& Renkl 1995; Reinmann-Rothmeier \& Mandl 1997:103). The stimulation of thought processes through content, strategic or motivational impulses or the so-called 'guided participation' of the children can contribute to individual learning support (Krammer 2010). Ideally, the children's own constructive achievements - for example, in their handling of the material that has been made available - form the point of departure for pedagogical intervention (Royar \& Streit 2010). This must be deliberately designed and also always requires an analysis of the educational goals that one wishes to achieve as well as the skills one wants to encourage (Fthenakis 2003; Fthenakis et al. 2005).

\section{The model as orientation framework for the actions of teachers}

The following example ${ }^{4}$ shows how the teacher-commencing with the activities of the children who make free use of the available material - first considers subject-specific aspects by spontaneously giving impulses and consciously promoting certain aspects. During the course of the lesson, the teacher then takes up one of the children's topics and focuses on interdisciplinary aspects (Streit 2010).

During free play, a number of children play with various geometric wooden figures. The so-called 'Pattern Blocks' represent aesthetically appealing material that encourages children to engage in various activities. Most of the children make pictures and patterns: Tobias builds a robot with all sorts of shapes, Tina makes star-shaped rosettes with the rhombuses and Lea creates mirror-imaged characters. If one now looks at the products with subject-specific - in this case mathematical -'spectacles', they have one thing in common: in all the figures, the idea of symmetry becomes apparent: The robot shows vertical axial symmetry, the rosettes are multiply axially and rotationally symmetrical, Lea's product is vertically and horizontally axially symmetrical. Other symmetrical products are also created. There is such a large variety that the teacher decides to deal with the topic of symmetry in instructed sequences. In order to use the children's ideas as a point of departure, the teacher takes photographs of their products and gives them the task of drawing their patterns or pictures. She gives them paper and coloured pencils to use.

In the meantime, Julia has made a tower out of yellow, regular hexagons. When she runs out of hexagons, she looks for alternative shapes and discovers that she can make a regular hexagon with the same area from two red symmetrical trapeziums. She finds this so interesting that she tells the teacher about her discovery. She takes up the idea and asks Julia if there are other pattern blocks from which she could make a hexagon. Julia tries and tries and eventually proudly presents the teacher with a hexagon made out of six green equal-sided triangles. Other children join in and take up the idea of the tower. Tom now also wants to build a tower that is as tall as he is. Unfortunately, it always collapses before he reaches the correct height. The teacher gives a subject-specific impulse: 'Perhaps you could also make a row of figures that is exactly as long as Tom'. The suggestion meets with their 
approval, and a little whilst later, there are rows of pattern blocks of various lengths: one is as long as Tom, one as long as Luis, etc. During the follow-up discussion, the various lengths are discussed and the problem of comparability arises when various shapes are used as a unit of measurement. The products of the other children are also introduced and discussed.

During the next few days, all the children work on the topic of symmetry in prepared learning sequences. They start with the children's drawings and the photographs from the previous day and then go on to other pictures and objects that the teacher has brought along. During the discussion, the children's expressions, such as 'back-to-front' and the same again on the other side 'are used again and then gradually the term 'symmetry' is introduced. Next the children examine various pictures in groups to find (axial) symmetry. They discover that the use of a mirror or foldlines can be helpful. So-called 'symmetry-walks' and the opportunity to bring along their own symmetrical pictures or objects expands their view to symmetries in the man-made and living environment and results in the question as to why symmetry is such an important principle. The teacher does not answer this question directly, but rather lets the children be involved themselves: Armed with building material, the children discover that, for example, symmetrical bodies are particularly stable and that nonsymmetrical paper airplanes fly much less effectively than symmetrical ones. Finally, the children create symmetrical pieces of art. They are allowed to use stamps or stencils; however, the question is first and foremost how these 'building blocks' are arranged, so that they eventually create a simple or multiply symmetrical piece of art. In the final phase, the focus is on the aesthetic aspect of the work of art. A child has deliberately included an element that breaks the symmetry. What effect does this have on the observer?

In the example, the children's activities and their resultant products are deliberately used by the teacher in order to give impulses that are based on subject-specific considerations and goals. Mathematically, rich activities are thus developed from the free play and with corresponding instructional support by the teacher. On the basis of concrete actions and by using the various materials, fundamental mathematical content and processes are experienced, which facilitate intuitive access to the realm of ideas of Mathematics. One also speaks of 'fundamental ideas': The concept of 'fundamental ideas' goes back to Bruner (1970). He assumes that the difference between the activities of the scientist and the child lies not primarily in the nature of the activity, but rather in the level. Every child should be taught each subject in a manner appropriate to him/her. In so doing, it is important to limit oneself to the fundamental ideas of the subject and then develop these further in a spiral pattern. These include, inter alia symmetry, measuring and part-whole relations - all three become visible in the above example of what happens in teaching during free play.

Initially, the teacher only influences the children's activities by providing them with the materials (Figure 2, Field 1). The

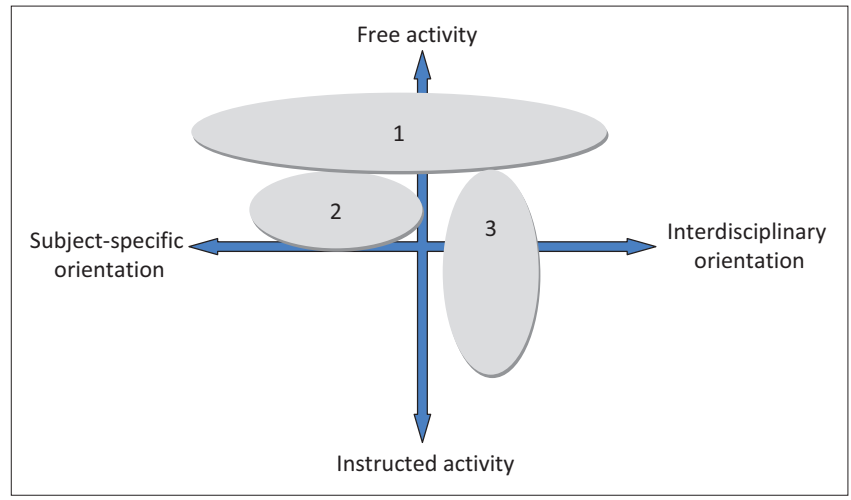

FIGURE 2: Location of the lesson sequences in the model.

invitation to draw the products that have been made implies a stronger control of the children's activities. The teacher gives no guidelines about the way the drawings should be made; the implementation of the instruction remains open and is also largely dependent on the children's drawing skills. At the same time, the instruction is selective and goal oriented because only those children are addressed whose products illustrate various symmetries. The question directed at Julia and the invitation to Tom point to the part-whole concept or to first experiences in measuring (to be more precise: to indirect comparisons with random units) and are thus explicitly anchored in Mathematics. The teacher's impulses encourage problem solving or provide assistance in the problem-solving process. In relation to the model, movement has taken place in the direction of stronger control and focussing on subject aspects (Figure 2, Field 2). Starting with the ideas and products from the children, the teacher decides to deal with the topic of symmetry in depth and in an interdisciplinary manner. In order to do this, she prepares relevant tasks and reflects on the results together with the children. This has to do with a learning arrangement for the whole group; however, the focus no longer lies only on the mathematical aspects of symmetry; now interdisciplinary aspects are dealt with in making use of the topic of symmetry. Nevertheless, the mathematical discoveries on symmetry can assist the children in recognising symmetries in their natural and man-made environment, as well as in understanding and consciously using the design or mechanical element. In this way, for example, connections can be made to aesthetic and technical education. Prerequisites for this are impulses and questions that challenge the children to constructively interconnect various points of access to phenomena. Then the insight gained from the different subjects and educational areas can lead to a more in-depth understanding of the relevant phenomena and give various points of access to reality. The teacher controls the children's activities to varying degrees; there are free and instructed activities for the children, but all are related to a given topic. The movement in the model is now in the direction of 'interdisciplinary orientation' (Figure 2, Field 3).

One could locate the illustration of the complex lesson process in an even more differentiated manner. However, it must suffice here to show that the teacher makes use of the entire spectrum of the model. Her actions are geared towards subject and interdisciplinary goals by incorporating the children's activities and the products created by them. 
In so doing, she makes use of different forms of control and different intensities of control of the children's activities.

\section{Towards teacher education and professional development}

The model that has its foundation in theory and its place in the practice of teaching can serve as a framework in training of teachers in preservice programmes as well as in teacher inservice development programmes. The aim is that teachers should use the full range of both dimensions and, through their pedagogical activity, relate the two poles that are often seen as opposites, with each other and integrate them with each other. Thus, it would become an instrument of analysis and reflection for one's personal teaching and for the teaching of others. Patterns of behaviour as well as 'blind spots' could then become apparent and, where necessary, be changed.

The application and implementation of the model requires diverse skills that can be characterised and described in terms of the individual poles of the dimensions. These include, inter alia, observation and/or diagnostic skills, by means of which children can, for example, be assessed through free activities in relation to their development or, in discussions, the children's way of thinking can be understood. From this, one can then deduce the consequences for teaching or, in terms of scaffolding, consciously promote learning activities in suitable situations. Over and above that, subject and subject-didactical skills are necessary in order to spot the subject-specific content in the activities of the children and then to support them in a sustainable manner in their learning processes and to make use of adequate learning materials. These subject and subject-didactical skills then form the precondition for recognising educationally relevant connections between subjects and educational areas and for implementing them in the form of interdisciplinary teaching (Di Giulio et al. 2008).

The requirements described above are highly demanding and it is only possible to a limited degree to deal with them properly within the framework of basic training. However, the model offers the opportunity of designing training and further training coherently based on theory and relating them to one another. An explicit placement of training and furthertraining phases or individual learning sequences in the model enables one to focus on those aspects of teaching that one wishes to concentrate on, without losing the awareness of the complexity of the teaching process.

The model also makes the processing of other interconnecting questions from various subject areas possible and thus creates a wide base for communication between representatives of training and further-training. On the one hand, subjectspecific aspects can be worked out within the framework of interdisciplinary topics and it can be described to what extent they complement or enrich one another. On the other hand, in practical professional studies, that particular aspect can be reflected upon and developed that indicates how the activities of the observed children can be supported in order to optimally promote subject learning by latching onto their experiences.

\section{Competing interests}

The authors declare that they have no financial or personal relationships which may have inappropriately influenced them in writing this article.

\section{Authors' contributions}

C.S. (University of Applied Sciences and Arts Northwestern), C.K.D. (University of Applied Sciences and Arts Northwestern) and E.H.(University of Applied Sciences and Arts Northwestern) contributed equally to the writing of this article.

\section{References}

Alfieri, L., Brooks, P.J., Aldrich, N., Tenenbaum, J. \& Harriet, R., 2011, 'Does discovery based instruction enhance learning?' Journal of Educational Psychology 103, Jg., Heft1, 1-18.

Blumenberg, H., 1980, Die Lesbarkeit der Welt, Suhrkamp, Frankfurt.

Bruner, J.S., 1970, Der Prozess der Erziehung, Cornelsen Verlag, Berlin.

Bülow, K., 2011, Anschlussfähigkeit von Kindergarten und Grundschule. Rekonstruktion von subjektiven Bildungstheorien von Erzieherinnen und Lehrerinnen, Klinkhardt, Bad Heilbrunn.

Deci, E.L. \& Ryan, R.M., 1985, Intrinsic motivation and self-determination in human behavior, Plenum, New York.

Deci, E.L. \& Ryan, R.M., 1993, Die Selbstbestimmungstheorie der Motivation und ihre Bedeutung für die Pädagogik, viewed 30 April 2014, from https:// selfdeterminationtheory.org/SDT/documents/1993_DeciRyan_DieSelbstbestimm ungstheoriederMotivation-German.pdf

Di Giulio, A., Künzli David, Ch. \& Defila, R., 2008, 'Bildung für eine nachhaltige Entwicklung und interdisziplinäre Kompetenzen - Zum Profil von Lehrkräften', in I. Bormann \& G. de Haan (Hrsg.), Kompetenzen der Bildung für nachhaltige Entwicklung. Operationalisierung, Messung, Rahmenbedingungen, Befunde, $\mathrm{pp}$. 179-197, VS Verlag für Sozialwissenschaften, Wiesbaden.

Draude, W., 2006, 'Droht der Kindergarten zu verschulen?' in GEW (Hrsg.), Dokumentation zur Tagung der Friedrich-Ebert-Stiftung in Zusammenarbeit mit der GEW Baden-Württemberg und dem Bundesverband Ev. ErzieherInnen und SozialpädagogInnen, pp. 33-40, Fritz-Erler-Forum, Stuttgart, viewed 11 March 2014, from http://library.fes.de/pdf-files/bueros/stuttgart/04839.pdf

Duncker, L., 1997a, 'Prinzipien einer Didaktik der Vielfalt', in S. Reinhardt \& E. Weise (Hrsg.), Allgemeine Didaktik und Fachdidaktik. Fachdidaktiker behandeln Probleme ihres Unterrichts, pp. 174-190, Deutscher Studienverlag, Weinheim.

Duncker, L., 1997b, Vom Sinn des Ordnens. Zur Rekonstruktion der Wirklichkeit in und zwischen den Schulfächern in L. Duncker \& W. Popp (Hrsg.), Über in und zwischen den Schulfächern, in L. Duncker \& W. Popp (Hrsg.), Uber
Fachgrenzen hinaus. Chancen und Schwierigkeiten des fächerübergreifenden Fachgrenzen hinaus. Chancen und Schwierigkeiten des fächerübergreifenden
Lehrens und Lernens. Bd. 1 Grundlagen und Begründungen, pp. 199-134, Dieck, Heinsberg.

EDK, 2007, HarmoS-Konkordat. Interkantonale Vereinbarung über die Harmonisierung der obligatorischen Schule, viewed 11 November 2012, from http://edudoc.ch/ der obligatorischen Schule, viewed
record/24711/files/Harmos_d.pdf

Fthenakis, W.E., 2003, Pädagogische Qualität in Tageseinrichtungen für Kinder, in W.E. Fthenakis (Hrsg), Elementarpädagogik nach Pisa. Wie aus Kindertagesstätten Bildungseinrichtungen werden können, pp. 208-242, Herder, Freiburg

Fthenakis, W.E., Gisbert, K., Griebel, W., Kunze, H.-R., Niesel, R. \& Wustmann, C., 2005 , Auf den Anfang kommt es an: Perspektiven für eine Neuorientierung frühkindlicher Bildung, Bundesministerium für Bildung und Forschung, Berlin.

Geigle, M., 2005, Konzepte zum fächerübergreifenden Unterricht. Eine historischsystematische Analyse ihrer Theorie, Dr. Kovac, Hamburg.

Giest, H., 2012, 'Lernen und Lehren im Sachunterricht - Zum Verhältnis von Konstruktion und Instruktion', in H. Giest, E. Heran-Dörr \& C. Archie (Hrsg.), Lernen und Lehren im Sachunterricht. Zum Verhältnis von Konstruktion und Instruktion, pp. 119-126, Klinkhardt, Kempten.

Goodson, I.F., Hoppmann, S. \& Riquarts, K., 1999, '(Hrsg.): Das Schulfach als Handlungsrahmen. Vergleichende Untersuchung zur Geschichte und Funktion der Schulfächer', in Böhlau, Köln, Weimar, Wien.

Griebel, W. \& Niesel, R., 2002, Abschied vom Kindergarten - Start in die Schule. Grundlagen und Praxishilfen für Erzieherinnen, Lehrkräfte und Eltern, Don Bosco, München.

Hardy, I., Jonen, A., Möller, K. \& Stern, E., 2006, 'Effects of instructional support within constructivist learning environments for elementary school students' understanding "Floating and Sinking"', Journal of Educational Psychology 98, Jg., Heft 2, 307-326. 
Honig, M.-S., Joos, M. \& Schreiber, N., 2004, Was ist ein guter Kindergarten? Theoretische und empirische Analysen zum Qualitätsbegriff in der Pädagogik, Juventa: Weinheim/München.

Huber, L., 2001, 'Stichwort: Fachliches Lernen. Das Fachprinzip in der Kritik. Theodor Schulze zum 75. Geburtstag gewidmet', Zeitschrift für Erziehungswissenschaften 4, Jg., Heft 3, 307-331.

Huber, L., 2009, 'Fachunterricht und Fächerübergreifender Unterricht', in F. Mertens \& L. Böhm (Hrsg.), pp. 398-411.

Kahlert, J., 1997, 'Vielseitigkeit statt Ganzheit. Zur erkenntnistheoretischen Kritik an einer pädagogischen Illusion', in L. Duncker \& W. Popp (Hrsg.), Über Fachgrenzen hinaus. Chancen und Schwierigkeiten des fächerübergreifenden Lehrens und Lernens. Bd. 1 Grundlagen und Begründungen, pp. 91-118, Dieck, Heinsberg.

Klafki, W., 1998, 'Fächerübergreifender Unterricht - Begründungsargumente und Verwirklichungsstufen', Rupert Vierlinger zum 65. Geburtstag gewidmet, in S. Popp (Hrsg.), Grundrisse einer humanen Schule, pp. 41-57, Studien Verlag, Innsbruck.

Klahr, D. \& Nigram, M., 2004, 'The equivalence of learning paths in early science instruction: Effect of direct instruction und discovery learning', Psychological Science 15, Jg., Heft 10, 661-667.

Kluczniok, K., Rossbach, H.-G. \& Grosse, Ch., 2010, 'Fördermöglichkeiten im Kindergarten. Ein Systematisierungsversuch', in A. Diller, H.R. Leu \& T. Rauschenbach (Hrsg.), Wie viel Schule verträgt der Kindergarten? Annäherung zweier Lernwelten, pp. 133-152, Verlag Deutsches Jugendinstitut, München.

Krammer, K., 2010, 'Individuelle Unterstützung im Unterricht mit 4- bis 8-jährigen Kindern', in M. Leuchter (Hrsg.), Didaktik für die ersten Bildungsjahre. Unterricht mit 4- bis 8-jährigen Kindern, pp. 36-48, Klett und Balmer, Zug.

Künzli David, Ch. \& Bertschy, F., 2010, 'Bildung für eine Nachhaltige Entwicklung als fächerübergreifendes Bildungskonzept', in J. Penzel \& F. Meinel (Hrsg.), Gestalten und Bilden. Methodendiskurs als Impuls für den Unterricht, pp. 137-147, kopaed, München.

Mandl, H., Gruber, H. \& Renkl, A., 1995, Situiertes Lernen in multimedialen Lernumgebungen, Ludwigs-Maximilian-Universität. Institut für Pädagogische Psychologie und Empirische Pädagogik, München.

Mertens, G., Frost, U. \& Böhm, W., 2009, (Hrsg.): Handbuch der Erziehungswissenschaft, Ferdinand Schöningh, Paderborn.

Meyer, R.E., 2004, 'Should there be a three-strikes rule against pure discovery learning?' The American Psychologist 59, Jg., Heft1, 14-19.

Meyer, R.E., 2009, 'Constructivism as a theory of learning versus constructivism as a prescription for instruction', in S. Tobias \& T.M. Duffy (Hrsg.), Constructivist Instruction. Success or Failure?, pp. 184-200, Routledge Publishing, New York.

Möller, K., 2012, 'Konstruktion vs. Instruktion oder Konstruktion durch Instruktion? Konstruktionsfördernde Unterstützungsmassnahmen im Sachunterricht', in H.
Giest, E. Heran-Dörr \& C. Archie (Hrsg.), Lernen und Lehren im Sachunterricht. Giest, E. Heran-Dörr \& C. Archie (Hrsg.), Lernen und Lehren im Sachunterricht.
Zum Verhältnis von Konstruktion und Instruktion, pp. 37-50, Klinkhardt, Zum Verhär.

NICHD Early Child Care Research Network, 2002, 'Early child care and children's development prior to school entry: Results from the NICHD study of early child development prior to school entry: Results from the NICHD study of early child
care', American Educational Research Journal 39(1), 133-164, viewed 30 April care', American Educational Research Journal 39(1), 133-164, view
2014, from http://www.jstor.org/stable/3202474?origin=JSTOR-pdf

Niesel, R., Griebel, W. \& Netta, B., 2008, Nach der Kita kommt die Schule. Mit Kindern den Übergang schaffen, Herder, Freiburg im Breisgau.

Piaget, J. \& Szeminska, A., 1975, Die Entwicklung des Zahlbegriffs beim Kinde, Ernst Klett, Stuttgart.

Popp, W., 1997, 'Die Spezialisierung auf Zusammenhänge als regulatives Prinzip der Didaktik', in L. Duncker \& W. Popp (Hrsg.), Über Fachgrenzen hinaus. Chancen und
Schwierigkeiten des fächerübergreifenden Lehrens und Lernens. Bd. 1 Grundlagen und Begründungen, pp. 135-154, Dieck, Heinsberg.

Reinmann-Rothmeier, G. \& Mandl, H., 1997, 'Kompetenzen für das Leben in einer Wissensgesellschaft', in S. Höfling \& H. Mandl (Hrsg.), Lernen für die Zukunft. Lernen in der Zukunft, pp. 97-107, Hanns-Seidel-Stiftung, München.

Rogoff, B., 1990, Apprenticeship in thinking: Cognitive development in social context, Oxford University Press, New York.

Rossbach, H.-G., 2010, 'Bildungs- und Lernverläufe im Übergang', in A. Diller, H.R. Leu \& T. Rauschenbach (Hrsg.), Wie viel Schule verträgt der Kindergarten? Annäherung zweier Lernwelten, pp. 75-90, Verlag Deutsches Jugendinstitut, München.

Rossbach, H.-G., Grosse, Ch., Kluczniok, K. \& Freund, U., 2010, 'Bildungs- und Lernziele im Kindergarten und in der Grundschule', in M. Leuchter (Hrsg.), Didaktik für die ersten Bildungsjahre. Unterricht mit 4- bis 8-jährigen Kindern, pp. 36-48, Klett und Balmer, Zug.

Roux, S., 2008, 'Bildung im Elementarbereich', in F. Hellmich \& H. Köster (Hrsg.), Vorschulische Bildungsprozesse in Mathematik und Naturwissenschaften, pp. 13-26, Klinkhardt, Kempten

Royar, T. \& Streit, Ch., 2010, Mathelino - Kinder begleiten auf mathematischen Entdeckungsreisen, Kallmeyer, Seelze.

Siraj-Blatchford, I., 2007, 'Creativity, communication and collaboration: The identification of pedagogic progression in sustained shared thinking', Asia-Pacific Journal Research Early Childhood Education 1, Jg., Heft 2, 3-23.

Streit, Ch., 2010, 'Fundamentale Ideen der Mathematik - auch im Kindergarten?' TPS 2010, 10. Jg., 4-7.

Sylva, K., Melhuish, E.C., Sammons, P., Siraj-Blatchford, I. \& Taggart, B., 2004, The Effective Provision of Pre-School Education (EPPE) Project: Technical Paper 12 The Final Report: Effective Pre-School Education, DfES/Institute of Education, University of London, London, viewed 29 April 2014 from http://www.ioe.ac.uk/ EPPE_TechnicalPaper_12_2004.pdf

Tenorth, H.-E., 1999, 'Unterrichtsfächer - Möglichkeit, Rahmen und Grenze', in Goodson, Hoppmann \& Riquarts (Hrsg.), pp. 191-207.

Terhart, E., 2008, 'Allgemeine Didaktik: Traditionen, Neuanfänge, Herausforderungen' Zeitschrift für Erziehungswissenschaft, 2008(Sonderheft 9), 13-34.

Valsangiacomo, F., Widorski, D. \& Künzli David, Ch., 2014, 'Bildungstheoretische Überlegungen' zu fächerübergreifendem Unterricht - Systematik transversalen Unterrichtens', Zeitschrift für die Didaktik der Gesellschaftswissenschaften 1(5), 21-39, Schwalbach/Ts: Wochenschau-Verlag.

Vogt, F., 2010, 'Curriculare und strukturelle Entwicklungen in der Schweiz', in M Leuchter (Hrsg.), Didaktik für die ersten Bildungsjahre. Unterricht mit 4- bis 8-jährigen Kindern, pp. 49-57, Klett und Balmer, Zug.

Wannack, E., 2004, Kindergarten und Grundschule zwischen Annäherung und Abgrenzung, Waxmann, Münster.

Wannack, E., 2010, 'Bildung von 4- bis 8-jährigen Kindern: Grundlagen und Konzepte im Wandel', in M. Leuchter (Hrsg.), Didaktik für die ersten Bildungsjahre. Unterricht mit 4- bis 8-jährigen Kindern, pp. 18-35, Klett und Balmer, Zug.

Wannack, E., Arnaldi, U. \& Schütz, A., 2009, 'Überlegungen zur Didaktik des Kindergartens', Zeitschrift 4bis8 99, Jg., Heft 9, 24-26.

Wannack, E., Schütz, A. \& Arnaldi, U., 2009, 'Die Spiel- und Lernbegleitung im Kindergarten', Zeitschrift 4bis8 99, Jg., Heft 12, 23-25.

Wannack, E., Sörensen, C.B. \& Gilléron, G.P., 2006, Frühere Einschulung in der Schweiz. Ausgangslage und Konsequenzen, Schweizerische Konferenz der kantonalen Erziehungsdirektoren, Bern, viewed 11 November 2012, from http://edudoc.ch/ record/17369/files/StuB26A.pdf

Weinert, F.E. \& Helmke, A., 1997, Entwicklung im Grundschulalter, Beltz, Weinheim. 